\title{
Interrelationships of Gibberellic Acid and Nitrate in Sugar Production and Enzyme Activity of Sugarcane
}

\author{
Alex G. Alexander ${ }^{1}$
}

\section{INTRODUCTION}

Both nitrate stress $(1,2,3)^{2}$ and foliar treatment with gibberellic acid (4) are known to alter the sugar-forming capacity of sugarcane. Work at this Station with nitrate $\left(\mathrm{NO}_{3}\right)$ and gibberellic acid (GA) has progressed sufficiently so that each can be used to raise leaf-sucrose production with considerable certainty. However, GA apparently stimulates both growth and sucrose production ${ }^{3}$, whereas increasing nitrate seems to promote growth at the expense of sucrose synthesis $(1,2)$.

Several questions therefore arise as to field usage of GA in areas of high nitrogen fertilization: 1 , To what degree can nitrate be withheld from the plant before growth decline offsets sucrose gains? 2, To what extent will increasing $\mathrm{NO}_{3}$ supply offset the beneficial effects of GA application? 3 , Is there a combination of high $\mathrm{NO}_{3}$ and GA which will permit both increased tonnage and increased sucrose synthesis as simultaneous effects? This paper summarizes greenhouse and laboratory studies aimed at clarifying nitrogen-GA relationships in immature sugarcane.

\section{MATERIALS AND METHODS}

One-eye cuttings of the variety P.R. 980 were planted in $\mathrm{HCl}$-washed "silica shot" contained in glazed, 2-gallon pots with glass wool over the drainage outlets. All seedlings received daily 1 liter of a complete nutrient solution ${ }^{4}$ until treatments were begun at 12 weeks of age. A $3 \times 3$ factorial design was established with three levels each of $\mathrm{NO}_{3}$ and $\mathrm{GA} . \mathrm{NO}_{3}$ was given at rates of 0,5 , and 30 meq./liter. From past experiments it is felt that "luxury consumption" of $\mathrm{NO}_{3}$ begins at about 10 meq./liter. Thus, the 5 meq./liter treatment was an attempt to secure near-optimum growth plus the sucrose stimulatory effects of $\mathrm{NO}_{3}$ deficiency. The 30 meq./liter treatment was purposely excessive, and zero $\mathrm{NO}_{3}$ was aimed at securing

${ }^{1}$ Associate Plant Physiologist, Agricultural Experiment Station, Mayagüez Campus, University of Puerto Rico, Río Piedras, P.R.

${ }^{2}$ Italic numbers in parentheses refer to Literature Cited, pp. 27-8.

${ }^{3}$ Unpublished data.

${ }^{4}$ Nutrient concentrations, expressed as meq./liter, were supplied as follows: Nitrate, 10; phosphorus, 6 ; potassium, 5; calcium, 3; magnesium, 2; and sulfur, 2. Micronutrients, expressed as p.p.m., were given as follows: Iron, 1.0; boron, 0.05 ; copper, 0.02; manganese, 0.50; Zine, 0.05; and molybdenum, 0.01 . 
nutritional stress with concurrent sucrose increases. GA was applied once as a foliar spray. The 10-percent potassium salt was used in amounts equal to $0,0.01-$, and 0.10 -percent solutions of the pure acid. Tween-20 was employed as wetting agent and all above-sand portions of the plants were sprayed until runoff had begun. The high GA level was already known to be in excess of that needed for optimum sucrose synthesis, under conditions of moderate $\mathrm{NO}_{3}$ status.

A single harvest was made 5-weeks following treatment. Leaves +1 to +4 and immature storage tissue (meristem) were frozen in a mixture of Dry Ice and acetone, lyophilized, and ground to a fine powder in accordance with procedures described previously (1).

Clarified water extracts of the plant powder were analyzed for total ketose by the method of Roe (11), and for sucrose by the modification of Cardini et al. (10). Fructose was estimated by subtracting sucrose values from those of total ketose. Protein was precipitated from water extracts with solid ammonium sulfate, as described earlier (1), and employed for enzyme assay without dialysis. Phosphatase and ATP-ase was measured by techniques described previously (5), as was $\beta$-amylase (6), polyphenol oxidase (7), and peroxidase (8). Protein content of the enzyme preparations was determined by the method of Sutherland et al. (12) and enzyme action was recorded as specific activity (activity units per milligram of protein).

\section{RESULTS AND DISCUSSION}

\section{FRESH-WEIGHT RESPONSES}

Considering that the plants were all healthy at the initial treatment, and that the experiment extended only 5 weeks, the changes in plant weight and appearance were remarkable. Medium GA caused general internode elongation while retaining stockiness of the cane. High GA induced more extensive elongation, so that the canes exhibited a weak and spindly condition plus occasional lodging.

Both $\mathrm{NO}_{3}$ and GA caused moderate growth increases as evidenced by fresh weights (table 1). Generally, the high treatments were in excess of that needed for maximum growth as main effects, yet a combination of high $\mathrm{NO}_{3}$ and medium GA gave the greatest yield of the study. Curiously, raising GA to high completely eliminated all $\mathrm{NO}_{3}$ growth increases. The reader should also note that withholding $\mathrm{NO}_{3}$ did not severely curtail growth when high GA was applied, and that these plants grew comparably to those given high $\mathrm{NO}_{3}$ plus zero GA. One might surmise that GA can work well with $\mathrm{NO}_{3}$ in promoting growth only if GA is used sparingly. 
TABLE 1.-Mean values for fresh weights of sugarcane supplied with variable gibberellic acid and nitrate in sand culture ${ }^{1}$

\begin{tabular}{|c|c|c|c|c|}
\hline \multirow{2}{*}{$\mathrm{NO}_{3}$ (meq./liter) } & \multicolumn{4}{|c|}{ Results when indicated grams per plant were supplied } \\
\hline & $\mathrm{GA}_{0}$ & $\mathrm{GA}_{0.01}$ & $\mathrm{GA}_{0.10}$ & Mean \\
\hline 0 & 80 & 122 & 130 & 111 \\
\hline 5 & 126 & 132 & 136 & 131 \\
\hline 30 & 128 & 162 & 122 & 137 \\
\hline Mean & 111 & 139 & 129 & \\
\hline
\end{tabular}

1 Each figure represents the computed mean of 3 replicates; 4 plants were harvested from each replicate.

TABLE 2.-Leaf and meristem sugar content of sugarcane treated with variable gibberellic acid and nitrate in sand culture ${ }^{1}$

\begin{tabular}{|c|c|c|c|c|c|c|c|c|c|c|c|c|}
\hline \multicolumn{13}{|c|}{ Leaf sugars (mg./g. of dry weight)- } \\
\hline \multicolumn{5}{|c|}{ Total ketose } & \multicolumn{4}{|c|}{ Sucrose } & \multicolumn{4}{|c|}{ Fructose } \\
\hline $\begin{array}{c}\mathrm{NO}_{3} \\
\text { (meq./liter) }\end{array}$ & $\mathrm{GA}_{0}$ & $\mathrm{GA}_{0.01}$ & $\mathrm{GA}_{0.10}$ & Mean & $\mathrm{GA}_{0}$ & $\mathrm{GA}_{0.01}$ & $\mathrm{GA}_{0.10}$ & Mean & $\mathrm{GA}_{0}$ & $\mathrm{GA}_{0.01}$ & $\mathrm{GA}_{0.10}$ & Mean \\
\hline 0 & 120 & 132 & 144 & 132 & 130 & 140 & 139 & 136 & 0 & 0 & 7 & 2 \\
\hline 5 & 107 & 118 & 121 & 115 & 98 & 118 & 112 & 109 & 9 & 2 & 9 & 7 \\
\hline 30 & 100 & 109 & 129 & 113 & 87 & 83 & 98 & 89 & 13 & 26 & 31 & 23 \\
\hline Mean & 109 & 119 & 131 & & 105 & 114 & 116 & 111 & 7 & 9 & 16 & \\
\hline
\end{tabular}

Meristem sugars (mg./g. of dry weight)-

\begin{tabular}{|c|c|c|c|c|c|c|c|c|c|c|c|c|}
\hline $\begin{array}{c}\mathrm{NO}_{3} \\
\text { (meq./liter) }\end{array}$ & $\mathrm{GA}_{0}$ & $\mathrm{GA}_{0,01}$ & $\mathrm{GA}_{0.10}$ & Mean & $\mathrm{GA}_{0}$ & $\mathrm{GA}_{0.01}$ & $\mathrm{GA}_{0.10}$ & Mean & $\mathrm{GA}_{0}$ & $\mathrm{GA}_{0.01}$ & $\mathrm{GA}_{0.10}$ & Mean \\
\hline 0 & 255 & 275 & 315 & 282 & 127 & 172 & 113 & 137 & 127 & 103 & 203 & 144 \\
\hline 5 & 315 & 284 & 335 & 311 & 91 & 132 & 89 & 104 & 224 & 152 & 246 & 207 \\
\hline 30 & 368 & 372 & 377 & 372 & 71 & 81 & 77 & 76 & 297 & 290 & 301 & 296 \\
\hline Mean & 313 & 310 & 342 & & 96 & 128 & 93 & 106 & 216 & 182 & 250 & \\
\hline
\end{tabular}

${ }^{1}$ Each figure represents the computed mean of three replicates.

\section{SUGAR RESPONSES}

Withholding $\mathrm{NO}_{3}$ succeeded in raising sucrose content in both leaf and meristem tissues (table 2). Sucrose was progressively suppressed by medium and high $\mathrm{NO}_{3}$. Fructose content was greatly increased by $\mathrm{NO}_{3}$. The latter suggests that inversion rather than total ketose synthesis was altered by the 
nitrogen treatments. GA slightly increased sucrose in leaves, and caused strong sucrose increases in storage tissue when $\mathrm{NO}_{3}$ was low. However, the GA effect was reduced progressively by increasing $\mathrm{NO}_{3}$ (fig. 1). As noted earlier (4) medium GA was superior to the high GA treatment in stimulating sucrose production. Thus while previous $\mathrm{NO}_{3}$ and GA effects on sucrose were again verified, in no instance did GA compensate for sucrose lost within increasing $\mathrm{NO}_{3}$ treatments.

It is concluded from sugar and fresh-weight data that the most favorable treatment was that which withheld $\mathrm{NO}_{3}$, and stimulated both growth and

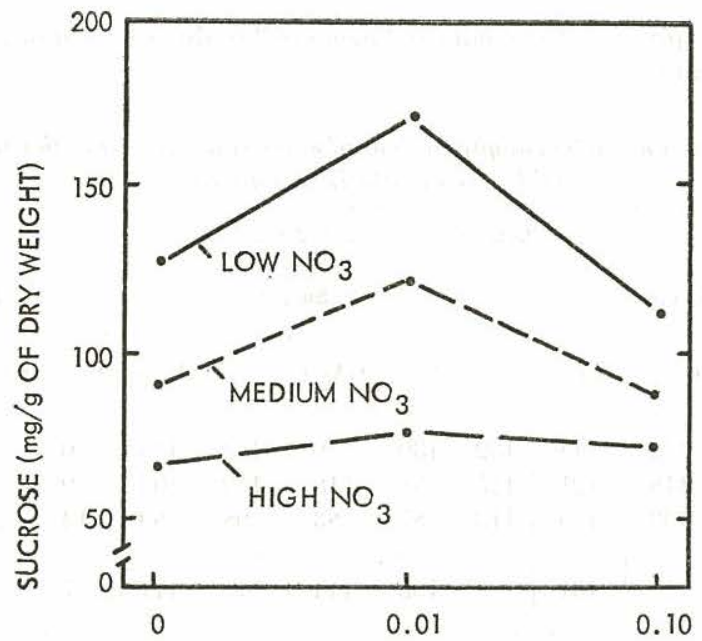

GA (PERCENT SOLUTION)

FIG. 1.-Sucrose content of immature storage tissue from sugarcane treated by foliar application of gibberellic acid, and grown with variable nitrate supply in sand culture.

sucrose production with medium GA. Greenhouse data are not directly applicable to field conditions, but the implication remains that GA treatment should be delayed after heavy nitrogen fertilization, and will not prove fully effective if given simultaneously with normal fertilizer programs.

\section{LEAF AND MERISTEM ENZYMES}

The most pronounced leaf-enzyme effects were the major stimulation of phosphatase and ATP-ase by $\mathrm{NO}_{3}$ (table 3 ). One might also say that these enzymes declined as $\mathrm{NO}_{3}$ was withheld, and this in itself might help account for much of the GA effects on sucrose. Biochemical consequences of exces- 
sive phosphatase and ATP-ase action are thoroughly discussed in an earlier report (1). Meristem enzyme data presented in table 4 underscore a striking $\mathrm{NO}_{3} \times$ GA interaction upon both hydrolytic and oxidative systems. Increasing $\mathrm{NO}_{3}$ levels severely retarded phosphatase and ATP-ase in the presence of high GA. Conversely, both enzymes were inhibited by increasing GA when $\mathrm{NO}_{3}$ was high. Peroxidase and polyphenol oxidase were likewise retarded by combining high $\mathrm{GA}$ and high $\mathrm{NO}_{3}$. However, unlike

TABLE 3.-Mean specific-activity values for leaf enzymes, and leaf-protein content of sugarcane treated with variable gibberellic acid and nitrate in sand culture ${ }^{1}$

\begin{tabular}{|c|c|c|c|c|c|c|c|c|c|c|c|c|}
\hline \multicolumn{13}{|c|}{ Leaf enzymes (specific activity) - } \\
\hline \multicolumn{5}{|c|}{ Phosphatase } & \multicolumn{4}{|c|}{ ATP-ase } & \multicolumn{4}{|c|}{$\beta$-amylase } \\
\hline$\underset{\text { (meq./ }}{\mathrm{NO}_{3}}$ & $\mathrm{GA}_{0}$ & $\mathrm{GA}_{0,01}$ & $\mathrm{GA}_{0.10}$ & Mean & $\mathrm{GA}_{0}$ & $\mathrm{GA}_{0.01}$ & $\mathrm{GA}_{0.10}$ & Mean & $\mathrm{GA}_{0}$ & $\mathrm{GA}_{0.01}$ & $\mathrm{GA}_{0.10}$ & Mean \\
\hline 0 & 3.6 & 4.0 & 4.6 & 4.1 & 4.6 & 4.9 & 5.3 & 4.9 & 3.7 & 3.8 & 3.4 & 3.6 \\
\hline 5 & 6.4 & 5.1 & 5.8 & 5.8 & 7.4 & 5.8 & 6.9 & 6.7 & 3.8 & 3.0 & 2.8 & 3.2 \\
\hline 30 & 7.4 & 7.2 & 5.7 & 6.8 & 9.6 & 9.1 & 7.0 & 8.6 & 2.7 & 2.9 & 3.0 & 2.9 \\
\hline Mean & 5.8 & 5.4 & 5.4 & & 7.2 & 6.6 & 6.4 & & 3.4 & 3.2 & 3.1 & \\
\hline \multicolumn{5}{|c|}{ Peroxidase } & \multicolumn{4}{|c|}{ Polyphenol oxidase } & \multicolumn{4}{|c|}{ Protein (mg./g. of dry weight) } \\
\hline$\underset{\text { (meq./ }}{\mathrm{NO}_{3}}$ & $\mathrm{GA}_{0}$ & $\mathrm{GA}_{0.01}$ & $\mathrm{GA}_{0.10}$ & Mean & $\mathrm{GA}_{0}$ & $\mathrm{GA}_{0.01}$ & $\mathrm{GA}_{0.10}$ & Mean & $\mathrm{GA}_{0}$ & $\mathrm{GA}_{0.01}$ & $\mathrm{GA}_{0.10}$ & Mean \\
\hline 0 & 15.1 & 20.7 & 21.0 & 18.9 & 15.7 & 15.4 & 17.5 & 16.2 & 8.0 & 7.4 & 7.4 & 7.6 \\
\hline 5 & 22.6 & 27.3 & 25.4 & 25.1 & 23.0 & 21.6 & 20.9 & 21.8 & 5.7 & 6.8 & 7.0 & 6.5 \\
\hline 30 & 23.1 & 21.8 & 26.5 & 23.8 & 22.0 & 21.4 & 18.2 & 20.5 & 6.2 & 6.7 & 7.7 & 6.9 \\
\hline Mean & 20.3 & 23.3 & 24.3 & & 20.2 & 19.5 & 18.9 & & 6.6 & 6.9 & 7.4 & \\
\hline
\end{tabular}

${ }^{1}$ Each figure represents the computed mean of 3 replicates.

phosphatase and ATP-ase, GA succeeded in activating the oxidases when when $\mathrm{NO}_{3}$ was withheld.

Evaluation of meristem protein values (table 4) helps clarify the above enzyme responses and gives insight into the action of both $\mathrm{NO}_{3}$ and GA. $\mathrm{NO}_{3}$ greatly increased protein and this effect was not reversed by GA. When GA was given, $\mathrm{NO}_{3}$ caused a threefold increase of protein. Since enzyme specific activity is computed on a protein basis, i.e., activity units per milligram of protein, it follows that specific activity decline from high $\mathrm{NO}_{3}$ may be offset by the greater amount of protein made available. One might visualize an enzyme dilution effect by high protein, but one which 
still permits an equal or greater amount of enzyme action to be accomplished.

Since GA stimulates growth it would not have been surprising to find increased protein content as a result of GA treatment. This did not occur. GA actually suppressed meristem protein when $\mathrm{NO}_{3}$ was low. The fact that GA does not increase protein synthesis, while $\mathrm{NO}_{3}$ does, may help explain the ability of GA to promote both growth and sugar formation. Growth stimulation by GA might reflect more efficient utilization of plant

TABLE 4.-Mean specific-activity values for meristem enzymes, and meristem protein content of sugarcane treated with variable gibberellic acid and nitrate in sand culture ${ }^{1}$

\begin{tabular}{|c|c|c|c|c|c|c|c|c|c|c|c|c|}
\hline \multicolumn{13}{|c|}{ Meristem enzymes (specific activity) } \\
\hline \multicolumn{5}{|c|}{ Phosphatase } & \multicolumn{4}{|c|}{ ATP-ase } & \multicolumn{4}{|c|}{$\beta$-amylase } \\
\hline$\underset{\begin{array}{c}\text { (meq./ } \\
\text { liter) }\end{array}}{\mathrm{NO}_{3}}$ & $\mathrm{GA}_{0}$ & $\mathrm{GA}_{0.01}$ & $\mathrm{GA}_{0.10}$ & Mean & $\mathrm{GA}_{0}$ & $\mathrm{GA}_{0.01}$ & $\mathrm{GA}_{0.10}$ & Mean & $\mathrm{GA}_{0}$ & $\mathrm{GA}_{0.01}$ & $\mathrm{GA}_{0.10}$ & Mean \\
\hline 0 & 9.5 & 9.7 & 10.5 & 9.9 & 11.0 & 10.5 & 10.2 & 10.6 & 6.8 & 5.5 & 6.9 & 6.4 \\
\hline 5 & 8.4 & 8.3 & 6.4 & 7.8 & 8.5 & 8.0 & 5.9 & 7.5 & 4.5 & 4.5 & 5.8 & 4.9 \\
\hline 30 & 9.0 & 8.0 & 5.7 & 7.6 & 9.1 & 7.4 & 4.9 & 7.1 & 5.8 & 5.2 & 5.3 & 5.4 \\
\hline Mean & 8.9 & 8.7 & 7.5 & & 9.5 & 8.6 & 7.0 & & 5.7 & 5.1 & 6.0 & \\
\hline \multicolumn{5}{|c|}{ Peroxidase } & \multicolumn{4}{|c|}{ Polyphenol oxidase } & \multicolumn{4}{|c|}{ Protein (mg./g. of dry weight) } \\
\hline $\begin{array}{c}\mathrm{NO}_{3} \\
\text { (meq./ } \\
\text { liter) }\end{array}$ & $\mathrm{GA}_{0}$ & $\mathrm{GA}_{0.01}$ & $\mathrm{GA}_{0.10}$ & Mean & $\mathrm{GA}_{0}$ & $\mathrm{GA}_{0.01}$ & $\mathrm{GA}_{0.10}$ & Mean & $\mathrm{GA}_{0}$ & $\mathrm{GA}_{0.01}$ & $\mathrm{GA}_{0.10}$ & Mean \\
\hline 0 & 9.2 & 12.6 & 16.3 & 12.7 & 11.2 & 16.8 & 18.0 & 15.3 & 15.4 & 9.5 & 9.7 & 11.5 \\
\hline 5 & 7.7 & 11.4 & 8.4 & 9.2 & 8.9 & 15.8 & 10.8 & 11.8 & 26.8 & 24.0 & 24.4 & 25.1 \\
\hline 30 & 8.3 & 8.5 & 7.5 & 8.1 & 10.2 & 8.9 & 9.5 & 9.5 & 26.3 & 29.9 & 29.3 & 28.5 \\
\hline Mean & 8.4 & 10.8 & 10.7 & & 10.1 & 13.8 & 12.8 & & 22.8 & 21.1 & 21.1 & \\
\hline
\end{tabular}

${ }^{1}$ Each figure represents the computed mean of 3 replicates.

constituents already available rather than a mobilization of additional materials. The fact that oxidases were stimulated by the same GA treatments which lowered protein synthesis (i.e., at the low $\mathrm{NO}_{3}$ level) leads one to suspect a more efficient regulation of catalytic protein.

In conclusion, it must be said that high $\mathrm{NO}_{3}$ cannot apparently be employed to increase growth simultaneously with GA-increased sugar synthesis. Of course, it is likely that high $\mathrm{NO}_{3}$ triggers a massive effort by the plant to add new tissues. The withholding of $\mathrm{NO}_{3}$ may simply restrain the plant and permit more subtle reactions to progress. On the other hand, 
recent work has shown that, when $\mathrm{NO}_{3}$ is in low supply, there are produced additional constituents related to nucleotides (9). These apparently contribute to the increased sucrose-forming potential of sugarcane. It might therefore be possible to provide these factors to the plant via secondary treatments, thereby permitting a combination of high $\mathrm{NO}_{3}$ and GA for greater growth and sugar production than is now possible.

\section{SUMMARY}

Variable nitrate $\left(\mathrm{NO}_{3}\right)$ and gibberellic acid $(\mathrm{GA})$ were applied to sugarcane in order to clarify $\mathrm{NO}_{3}$-GA interrelationships which affect growth, sugar production, and enzyme activity. Since both low $\mathrm{NO}_{3}$ and foliar GA were known to increase sucrose synthesis as separate entities, their combination posed the following questions: 1 , To what degree can $\mathrm{NO}_{3}$ be withheld before growth decline offsets sucrose gains? 2, To what extent will increasing $\mathrm{NO}_{3}$ supply offset the beneficial effects of GA application? 3 , Is there a combination of high $\mathrm{NO}_{3}$ and GA which will permit both increased tonnage and increased sucrose synthesis as simultaneous effects? Healthy, 12 -week-old plants grown in sand culture were treated for 5 weeks. Three levels each of $\mathrm{NO}_{3}(0,5$, and 30 meq./liter) and GA (0, 0.01-, and 0.10 -percent solutions of foliar spray) were given in a $3 \times 3$ factorial combination.

The following results were obtained:

1. Both $\mathrm{NO}_{3}$ and $\mathrm{GA}$ caused moderate growth increases as evidenced by fresh weights. A combination of high $\mathrm{NO}_{3}$ and medium GA gave the maximum yields recorded. Medium GA stimulated internode elongation while retaining stockiness of the cane. High GA caused excessive elongation plus weakening and occasional lodging of the plants.

2. High GA eliminated all $\mathrm{NO}_{3}$-induced growth increases. Withholding $\mathrm{NO}_{3}$ did not seriously curtail growth so long as GA was applied. Plants given GA without $\mathrm{NO}_{3}$ grew comparably to those receiving high $\mathrm{NO}_{3}$ without GA.

3. Withholding $\mathrm{NO}_{3}$ caused major sucrose increases in both leaf and immature storage tissues. Raising $\mathrm{NO}_{3}$ increased synthesis of total ketoses but caused striking decline of sucrose. GA caused significant sucrose increases in storage tissue when $\mathrm{NO}_{3}$ supply was low. However, GA-induced sucrose increases could not offset sucrose losses due to high $\mathrm{NO}_{3}$.

4. The most favorable treatment for growth and sugar production was a combination of low $\mathrm{NO}_{3}$ and medium GA. This induced moderate growth plus major sucrose increases.

5. Leaf phosphatase and ATP-ase were greatly stimulated by $\mathrm{NO}_{3}$. High GA alleviated the $\mathrm{NO}_{3}$ effects.

6. A strong $\mathrm{NO}_{3} \times \mathrm{GA}$ interaction affected both hydrolytic and oxidative 
enzymes in immature storage tissue. Phosphatase, ATP-ase, peroxidase and polyphenol oxidase were all involved.

7. $\mathrm{NO}_{3}$ greatly increased protein content of immature storage tissue, but GA had little effect. GA was able to stimulate both growth and sugar formation without the major protein changes characteristic of $\mathrm{NO}_{3}$ treatments. Practical usage of the $\mathrm{NO}_{3}$ and GA data are discussed. It is felt that GA treatment should be delayed after heavy nitrogen fertilization, and will not prove fully effective if given simultaneously with normal fertilizer programs.

\section{RESUMEN}

Se aplicaron diferentes niveles de nitrato $\left(\mathrm{NO}_{3}\right)$ y ácido giberélico (AG) a plantas de caña de azúcar, con el propósito de aclarar las interrelaciones de estos compuestos que afectan el crecimiento, la producción de azúcar y la actividad enzimática. Como ya se sabía que tanto un nivel bajo de $\mathrm{NO}_{3}$ como de AG en una aplicación foliar aumentan individualmente la síntesis de la sacarosa, la aplicación de estos compuestos en forma combinada sugería las siguientes preguntas: 1, ¿Hasta qué grado puede reducirse el $\mathrm{NO}_{3}$ sin que la disminución del crecimiento afecte los aumentos de la sacarosa? 2, ¿Hasta qué punto un aumento en la concentración del $\mathrm{NO}_{3}$ puede afectar la acción favorable de la aplicación del AG? 3, ¿Existe acaso una combinación de $\mathrm{AG}$ y $\mathrm{NO}_{3}$, a una concentración alta, cuyos efectos permitan simultánemente tanto un aumento en el tonelaje como en la síntesis de la sacarosa?

Se trataron plantas saludables de 12 semanas de sembradas y cultivadas en arena, durante un período de 5 semanas. Se aplicaron tres niveles de $\mathrm{NO}_{3}(0,5$ y 30 meq/l) y de $\mathrm{AG}$ (en forma de aspersión foliar con soluciones al $0,0.01$ y 0.10 por ciento) en un experimento de diseño factorial de $3 \times 3$.

Los resultados fueron los siguientes:

1. Los pesos húmedos indicaron que tanto el $\mathrm{NO}_{3}$ como el $\mathrm{AG}$ causaron un aumento moderado en el crecimiento. Se obtuvo el mayor rendimiento al combinarse el $\mathrm{NO}_{3}$, a una concentración alta, con el AG a una intermedia. La concentración intermedia de AG estimuló el alargamiento de los entrenudos, sin alterar el grosor de la caña. El AG a un nivel alto causó un alargamiento excesivo, y el debilitamiento y encamado ocasional de las plantas.

2. Los aumentos en el crecimiento inducidos por el $\mathrm{NO}_{3}$ cesaron en presencia de un nivel alto de $\mathrm{AG}$. La eliminación del $\mathrm{NO}_{3}$ no impidió seriamente el crecimiento siempre que se aplicó el AG. El crecimiento de las plantas que sólo se trataron con AG fue comparable al de las tratadas con un nivel alto de $\mathrm{NO}_{3}$, pero sin el $\mathrm{AG}$.

3. La eliminación del $\mathrm{NO}_{3}$ estimuló considerables aumentos de sacarosa, 
tanto en la hoja como en los tejidos tiernos donde se acumula. Al aumentarse el $\mathrm{NO}_{3}$, aumentó a su vez la síntesis de las cetosas totales pero esto causó una reducción del contenido de sacarosa. El AG produjo aumentos significativos de sacarosa en los tejidos donde se acumula cuando se suministró poca cantidad del $\mathrm{NO}_{3}$. Sin embargo, los aumentos de sacarosa inducidos por el AG no pudieron compensar las pérdidas de ésta causadas por un nivel alto de $\mathrm{NO}_{3}$.

4. El tratamiento más favorable para estimular el crecimiento y la producción de azúcar fue la combinación de un nivel bajo de $\mathrm{NO}_{3}$ y un nivel intermedio de AG. Esto indujo un crecimiento moderado y un aumento mayor de sacarosa.

5. La ATP-asa y la fostatasa foliares fueron muy estimuladas por el $\mathrm{NO}_{3}$. El AG a una concentración alta aminoró los efectos causados por el $\mathrm{NO}_{3}$.

6. Una fuerte interacción del $\mathrm{NO}_{3}$ y el AG afectó tanto las enzimas hidrolíticas como los oxidantes en los tejidos tiernos. También fueron afectadas la fosfatasa, la ATP-asa, la peroxidasa y la oxidasa de polifenol.

7. $\mathrm{El} \mathrm{NO}_{3}$ aumentó en grado sumo el contenido de proteína del tejido tierno, pero el AG apenas tuvo efecto alguno. El AG estimuló el crecimiento y la formación de azúcar sin que se registraran los grandes cambios en las proteínas que son característicos de los tratamientos con $\mathrm{NO}_{3}$.

Se discute la aplicadión práctica que puede hacerse de los resultados obtenidos en las pruebas con $\mathrm{NO}_{3}$ y AG. Se cree que la aplicación del AG debe posponerse hasta después que se abone a un nivel alto de nitrógeno, y que su acción no es plenamente efectiva cuando la aplicación se hace simultáneamente con las de los programas corrientes de abonamiento.

\section{LITERATURE CITED}

1. Alexander, A. G., Sucrose-enzyme relationships in immature sugarcane as affected by varying levels of nitrate and potassium supplied in sand culture, J. Agr. Univ. P. R. 48 (3): 165-231, 1964.

2. - Behavior of enzymes governing starch- and sucrose-forming pathways in two sugarcane varieties supplied with variable nitrate and phosphate in sand culture, J. Agr. Univ. P. R. 49 (2): 153-75, 1965.

3. - Effects of variable Diuron and nitrate on sucrose content plus enzyme activity of sugarcane grown in sand culture, J. Agr. Univ. P. R. 51 (4): 316-23.

4. - Effects of variable silicon and gibberellic acid on sugar and enzyme constituents of immature sugarcane grown in sand culture, Proc. Int. Soc. Sugar Cane Technol. Taiwan, 1968.

5. - Hydrolytic proteins of sugarcane: The acid phosphatases, J. Agr. Univ. P. R. 49 (2): 204-28, 1965.

6. - - Hydrolytic proteins of sugarcane: Amylase, J. Agr. Univ. P. R. 49 (3): 30824, 1965.

7. - Oxidizing enzymes of sugarcane: Tyrosinase, J. Agr. Univ. P. R. 50 (2): 113-30, 1966. 
8. - Oxidizing enzymes of sugarcane: Peroxidase, J. Agr. Univ. P. R. 50 (1): 36$52,1966$.

9. - - Nucleotides of sugarcane: Increased nucleotide content of leaves as a function of nutritional stress, J. Agr. Univ. P. R. 51 (3): 228-37, 1967.

10. Cardini, C. E., Leloir, L. F., and Chiriboga, J., The biosynthesis of sucrose, $J$. Biol. Chem. 214: 149-55, 1955.

11. Roe, J. H., A colorimetric method for the determination of fructose in blood and urine, J. Biol. Chem. 107: 15-22, 1934.

12. Sutherland, E. W., Cori, C. F., Haynes, R., and Olsen, N. S., Purification of the hyperglycemic-glycogenolytic factor from insulin and from gastric mucosa, J. Biol. Chem. 180: 825-37, 1949. 